\author{
Research Article \\ www.ijrap.net (ISSN:2229-3566)
}

\title{
A CLINICAL STUDY TO EVALUATE THE EFFECT OF JATAMANSYADI KWATHA AND SHIRODHARA IN THE MANAGEMENT OF HYPERTENSION
}

\author{
Vijay Chaudhary ${ }^{1 *}$, Ankita Agrawal ${ }^{2}$, Sameet Masand ${ }^{3}$ \\ ${ }^{1}$ Professor and H.O.D., P.G. Department of Kayachikitsa, R.G.G.P.G. Ayurvedic College, Paprola, Himachal Pradesh, \\ India \\ ${ }^{2}$ Research Scholar, P.G. Department of Kayachikitsa, R.G.G.P.G. Ayurveda College, Paprola, Himachal Pradesh, India \\ ${ }^{3}$ Assistant Professor, P.G. Department of Ras Shastra Evum Bhaishajya Kalpana V.Y.D.S. Ayurved Mahavidyalaya, \\ Khurja, Uttar Pradesh, India
}

Received on: 01/09/20 Accepted on: 22/02/21

\begin{abstract}
*Corresponding author
E-mail: drvijaychaudhary@gmail.com
\end{abstract}

DOI: 10.7897/2277-4343.120236

\begin{abstract}
Hypertension is emerging as a pandemic in the society. It can lead to severe health complications and increases the risk of many fatal diseases. Though a lot of potent antihypertensive drugs are available today but none of them is free from untoward effects. Due to these reasons the public acceptability for currently available antihypertensive drugs is very poor. The present study is aimed to evaluate the efficacy of an Ayurvedic formulation i.e., Jatamansyadi Kwatha and Shirodhara in the management of stage - I hypertension. Twenty patients of either sex of stage-I essential hypertension in the age group of 20-80 years were registered for the present study. Registered patients were randomly divided into two groups. In group-I, hypertensive patients were managed with Jatamansyadi Kwatha and in group-II patients, in addition to the administration of Jatamansyadi Kwatha, Shirodhara was also done. The duration of trial was 30 days. After one month of therapy, statistically highly significant reduction in both systolic B.P. and diastolic B.P. was observed in both groups. In group-II patients, statistically significant reduction in mean arterial B.P., pulse pressure and pulse rate were observed. Whereas in group-I, the effect of therapy on mean arterial B.P., pulse pressure and pulse rate were statistically insignificant. Therapy given in Group-II has shown the marginal advantage over the therapy given in Group-I. However statistically highly significant reduction was observed in both systolic and diastolic blood pressure in both the groups but the intergroup difference between the therapies was statistically insignificant.
\end{abstract}

Keywords: Hypertension, Jatamansyadi Kwatha, Shirodhara, Blood Pressure.

\section{INTRODUCTION}

Hypertension is defined as a systolic blood pressure (SBP) of 140 $\mathrm{mm} \mathrm{Hg}$ or more and/or a diastolic blood pressure (DBP) of 90 $\mathrm{mm} \mathrm{Hg}$ or more, or any level of blood pressure in the patients taking antihypertensive medication ${ }^{1}$. It can lead to severe health complications and increase the risk of many fatal diseases. Hypertension is a primary risk factor for cardiovascular disease, including stroke, heart attack, heart failure, and aneurysm. Keeping blood pressure under control is vital for preserving health and reducing the risk of these potentially serious conditions.

Recent data from Framingham Heart Study suggest that individuals who are normotensive at the age of 55 have a ninety percent risk for developing hypertension ${ }^{2}$. In clinical trials, antihypertensive therapy has been associated with reduction in stroke incidence averaging 35-40 percent; myocardial infarction, 20-25 percent; and heart failure, more than 50 percent. Recent clinical trials have demonstrated that effective blood pressure control can be achieved in most patients who are hypertensive. However, majority will require two or more antihypertensive drugs.

As per Ayurveda fundamental principles, the homeostasis of three basic humors Vata, Pitta and Kapha, seven Dhatus and Malas is required for maintaining optimum health. So particularly for the understanding of blood pressure in terms of Ayurveda, consideration of Rasa, Rakta, Dhatu, Srotas, Vyana Vayu, Sadhaka Pitta, Avalambaka Kapha and Oja are necessary.
Shonita is a Drava Dhatu. Therefore, it has a natural property of flowing. To ensure its supply up to the most distal tissues an additional force is required along with the natural property of flowing. This force is provided by the contraction and relaxation of heart. The functioning of Hridya comes under the domain of Vayu, particularly Vyana Vayu. When Vyana gets vitiated either it may lead to increased force of contraction of heart (leading to increased cardiac output) or increased contraction of blood vessels (leading to increased peripheral resistance) resulting in elevation of blood pressure ${ }^{3}$. It is also well-known fact that hypertension is also a Sarva Shareergata Vyadhi ${ }^{4}$ having wide spread systemic manifestations and complications so it is relevant to consider it Vyana Vikruti.

Essential hypertension is a disease of unknown etiology. So, modern physician tries to control this disease by giving symptomatic treatment. Anti-hypertensive drugs are prescribed to control the blood pressure as well as to check the further complication of the disease. In the modern system of medicine, a wide range of drugs are available for this disease with a much bigger range of associated untoward effects. On the contrary the herbs used in Ayurvedic system of medicine are time tested and comparatively safe and rarely cause any untoward effect. So, a safe polyherbal drug i.e., Jatamansi Kwath ${ }^{5}$ (Table 1) has been selected to evaluate its anti hypertensive effect.

Shirodhara is a procedure of pouring a liquid on forehead in a particular rhythm for a stipulated period of time. Dhara is an important therapeutic procedure used for the management of in many disease conditions. By bringing about changes in the Dhara 
Dravya and the procedure of Dhara, based upon the Doshik status, it proves as a unique and effective treatment modality. Dhara is particularly effective in the management of psychosomatic disease. It can be done by different medicaments like Taila, Takra, Kshira, Kwatha. In this study Shirodhara with Triphala ${ }^{6}$ Siddha Jala was done for first 10 days of commencement of trial drug in second group. (Table 2)

\section{Aims and Objectives}

- To evaluate the efficacy of Jatamansi Kwath and Shirodhara in the management of essential hypertension.

- To evaluate the clinical safety of Jatamansi Kwath and Shirodhara in the patients of essential hypertension.

\section{MATERIALS AND METHODS}

\section{Selection of patients}

A total of 20 uncomplicated patients of essential hypertension were selected for the present study from O.P.D. and I.P.D. of Kayachikitsa department, R.G.G.P.G. Ayurvedic College Hospital, Paprola, irrespective of their sex and socio-economic status, etc.

\section{IEC and Consent}

Approval from the Institutional Ethical Committee (IEC) vide letter no. Ayu/IEC/2015/1067 dated 11/08/2016 was taken prior to the commencement of study. Written \& informed consent of the patient was taken before their registration for the study.

\section{Criteria of Diagnosis}

Diagnosis was mainly based on readings of sphygmomanometer, with the help of sphygmomanometer, 3 consecutive readings of blood pressure in 3 different positions (sitting, standing and supine) on both arms were taken. Their mean value was calculated for each arm separately and the higher reading was utilized for diagnosing and categorizing the patients according to VII Joint National Committee on Detection, Education and Treatment of High Blood Pressure. To determine systolic and diastolic blood pressure the Korotkoff sound I and V were used.

Systolic B.P. - 140-159 mm of $\mathrm{Hg}$ and/or

Diastolic B.P. - 90-99 $\mathrm{mm}$ of $\mathrm{Hg}$

\section{Inclusion criteria}

- Patients willing for trial.

- Patients in age-group between 20-80 years.

- Patients suffering from stage-I hypertension were included in trial

- (Systolic blood pressure 140-159 $\mathrm{mmHg}$ and/or diastolic blood pressure $90-99 \mathrm{~mm}$ of $\mathrm{Hg}$ ) or isolated systolic hypertension (systolic blood pressure $>140 \mathrm{mmHg}$ and diastolic blood pressure $<90 \mathrm{~mm} \mathrm{Hg}$ )

\section{Exclusion criteria}

- Patients not willing for the trial.

- Patients below age of 20 years and above 80 years. of age.

- Stage-II hypertension i.e. Systolic B.P. > $160 \mathrm{~mm}$ of $\mathrm{Hg}$ and/or Diastolic B.P. $>100 \mathrm{~mm}$ of $\mathrm{Hg}$

- Any other patients considered unfit for inclusion in trial after investigation.

\section{Laboratory investigations}

Following laboratory investigations were carried out in the register patients to confirm the diagnosis and to rule out other concomitant disease both before and after the therapy.

- Routine hematological tests: HB g\%, TLC, DLC, ESR.

- Biochemical tests: FBS, Blood Urea, Serum Creatinine, Lipid profile (LDL, VLDL, HDL, S. Triglycerides, S. Cholesterol)

- Urine examination: Routine, Microscopic

- Chest X-Ray PA view

- E.C.G.

\section{Method of Study}

\section{Trial groups}

Total 20 patients of essential hypertension were registered on the basis of selection criteria. These patients were randomly divided into two groups i.e., Group-I and Group-II with 10 patients in each group. All registered patients completed the study.

\section{Group-I}

Total 10 patients were registered in trial Group-I. The selected patients were given the trial drug i.e., Jatamansyadi Kwatha - 50 $\mathrm{ml}(15 \mathrm{~g})$ twice a day with plain water after food.

\section{Group-II}

Total 10 patients were registered in trial Group-II. The selected patients were given the trial drug i.e., Jatamansyadi Kwatha - 50 $\mathrm{ml}(15 \mathrm{~g})$ twice a day with plain water after food. In addition to the administration of oral drug, Shirodhara with Triphala Siddha Jala was also done in this group for first 10 days of commencement of therapy.

Duration of trial: Duration of trial was 30 days.

All the registered patients were advised to reduce salt intake in their diet, avoid fatty and spicy food items and to take high fiber rich diet. They were also advised to stop smoking and other addictions if any. They were further advised to take relaxation exercises Shavasana and morning walks for 20-30 minutes at least 5 days in a week.

Registered patients were thoroughly assessed after every 15 days for any improvement in the objective (Table 3 ) and subjective criteria (Table 4), till the completion of trial period of 30 days. Various signs and symptoms were accorded grades according to the severity for the purpose of assessment. Hematological, biochemical and urine examination were done both before commencement and after completion of the therapy.

\section{DISCUSSION}

The maximum number of registered patients of stage-I hypertension in the present study i.e., $70 \%$ were found in the age group 21-40 years followed by $15 \%$ in the age group of 41-60 years and 61-80 years each (Table 5). Present study revealed that out of 20 patients, maximum i.e., $45 \%$ were doing house work, $35 \%$ were doing private jobs and $20 \%$ were retired from job (Table 6). Study on 20 patients of stage-I hypertension revealed that $75 \%$ had active life style, $15 \%$ of the patients were enjoying sedentary life style whereas $10 \%$ were doing hard work (Table 7 ). Out of 20 patients of stage-I hypertension, maximum number of patients i.e., $85 \%$ had habit of taking mixed diet while $15 \%$ were 
Vijay Chaudhary et al / Int. J. Res. Ayurveda Pharm. 12 (2), 2021

vegetarians (Table 8). Out of 20 patients of stage-I hypertension, in group I $10 \%$ patients had habit of smoking \& $10 \%$ alcohol, $30 \%$ both smoking and alcohol followed by $40 \%$ tea/ coffee and $10 \%$ had no addiction while in group II $20 \%$ patients had habit of smoking \& $10 \%$ alcohol, $40 \%$ both smoking and alcohol followed by $20 \%$ tea/ coffee and $10 \%$ had no addiction (Table 9 ). Out of 10 registered patients of stage-I hypertension in Group-I, 60\% (6) patients complained of Shiraruja, 40\% (4) patients complained of Bhrama, 20\% (2) patients complained of Hriddrava and 20\% (2) patients complained of Shwasa kricchrita. While out of 10 registered patients of stage-I hypertension in Group-II, 40\% (4) patients had Shiraruja, 20\% (2) had Bhrama, 20\% (2) had Hriddrava, 10\% (1) patients complained of Shwasa kricchrita. (Table 10)

Effects of the therapy revealed that mean systolic blood pressure before treatment in Group-I was $143.2 \mathrm{~mm}$ of $\mathrm{Hg}$ which dropped down to $137.6 \mathrm{~mm}$ of $\mathrm{Hg}$ at completion of one month of therapy with $3.916 \%$ reduction. Whereas in Group-II the mean systolic blood pressure before treatment was $146.2 \mathrm{~mm}$ of $\mathrm{Hg}$ which dropped to $123.6 \mathrm{~mm}$ of $\mathrm{Hg}$ at completion of trial with $11.85 \%$ reduction. The mean diastolic blood pressure before treatment in Group-I was $96.80 \mathrm{~mm}$ of $\mathrm{Hg}$ which dropped to $79.20 \mathrm{~mm}$ of $\mathrm{Hg}$ at completion of therapy with $3.373 \%$ reduction. Whereas in Group-II the mean diastolic blood pressure before treatment was $94.20 \mathrm{~mm}$ of $\mathrm{Hg}$ which dropped to $78.60 \mathrm{~mm}$ of $\mathrm{Hg}$ at completion of trial with $10.685 \%$ reduction. The reduction in both systolic and diastolic blood pressure in both the groups was statistically highly significant $(<0.001)$ (Table 11$)$. On comparing the inter group difference; Group-II showed statistically highly significant advantage over group-I in reduction of systolic blood pressure ( $\mathrm{p}$ $<0.001)$ and insignificant advantage in reduction of diastolic blood pressure $(p=0.439)$ (Table 15). Changes in mean arterial pressure were observed after the therapy in both the groups. In Group-I, initial mean score for mean arterial pressure was 103.7 $\mathrm{mm}$ of $\mathrm{Hg}$, which decreased to $97.56 \mathrm{~mm}$ of $\mathrm{Hg}$ after treatment with $5.8 \%$ reduction which was statistically insignificant $(\mathrm{p}=$ 0.063 ). In Group-II, initial mean score for mean arterial pressure was $107.77 \mathrm{~mm}$ of $\mathrm{Hg}$, which decreased to $97.31 \mathrm{~mm}$ of $\mathrm{Hg}$ after treatment with $5.3040 \%$ reduction which was statistically highly significant $(\mathrm{p}<0.001)$ (Table 12). On comparing the inter group difference; group-I showed statistically in significant advantage over group-II in reduction of mean arterial pressure (Table 15). Changes in pulse pressure were observed after the therapy in both the groups. In Group-I, initial mean score for pulse pressure was $56.40 \mathrm{~mm}$ of $\mathrm{Hg}$, which increased to $60.00 \mathrm{~mm}$ of $\mathrm{Hg}$ after treatment with $6.38 \%$ rise which was statistically insignificant $(p$ $=0.36$ ). In Group-II, initial mean score for pulse pressure was $52.00 \mathrm{~mm}$ of $\mathrm{Hg}$ which decreased to $45.00 \mathrm{~mm}$ of $\mathrm{Hg}$ after treatment with $13.4 \%$ reduction which was statistically significant $(\mathrm{p}=0.02)$. (Table 13) On comparing the inter group difference; group-II showed statistically insignificant advantage over group-I in reduction of pulse pressure (Table 14). In Group-I initial mean score for pulse rate was $81.8 / \mathrm{min}$. which decreased to $77.2 / \mathrm{min}$. after treatment with $5.6 \%$ reduction. In Group-II, initial mean score for pulse rate was $87.8 / \mathrm{min}$. which decreased to $82.4 / \mathrm{min}$. after treatment with $5.287 \%$ reduction. Statistical evaluation showed insignificant changes in pulse rate in both the groups $(p=0.231)$ after the therapy. On comparison the inter group difference, between the results observed in groupI and group-II was also statistically insignificant (Table 15).

Hemoglobin, TLC, DLC, ESR, FBS, Blood Urea and Serum Creatinine, SGOT, SGPT, data were within normal limits before starting of therapy and remained so after completion of trial in both the groups. Change in cholesterol observed after the therapy. In group-I initial mean score of cholesterol was 160.4 which decreased to 149.2 after treatment with $20.85 \%$ reduction. (Table
16) whereas in Group-II, initial mean score for Serum Cholesterol was 202.5, which decreased to 190.8 after treatment with $25.27 \%$ reduction. (Table 17) Statistically insignificant reduction in Serum Cholesterol was observed in Group-I after therapy whereas effect of therapy on Serum Cholesterol in Group-II was statistically significant. These observations are suggestive of the fact that Ayurvedic formulation Jatamansi Kwatha has got a potential of lowering elevated level of serum cholesterol in hypertensive patients. It also has a potential to alleviate the features like headache, giddiness, palpitation and dyspnoea. In Group-II patients, the effect of therapy on various subjective and objective parameters was better than group-I, where in addition to the administration of Jatamansi Kwatha, Shirodhara was also done.

The probable mode of action of each ingredient of drug is discussed on both Ayurveda as well as on modern grounds. Jatamansi has been described as a Tridoshaghna drug. It has tikta, kashaya, madhura rasa; laghu, snigdha guna; sheeta virya and katu vipaka. It is described as sangyasthapaka, medhya, nidrajanaka and mansika doshahara ${ }^{7}$. The pathogenesis of hypertension it is clearly shows that it is a vata pradhana tridoshaja vyadhi and Manovaha srotas is also involved in the pathogenesis. So Jatamansi being having Tridoshaghna properties breaks the pathogenesis of hypertension and lowers the elevated blood pressure to normal levels. Moreover, it also improves the Manovaha Srotodushti, which further helps in executing antihypertensive action. The essential oil and alkaloid fraction obtained from rhizomes of $N$. jatamansi experimentally exerted prolonged and pronounced hypotensive effects in animals. ${ }^{8}$ Due to these reasons Jatamansi was selected as one of the ingredients of poly-herbal trial compound. Ashwagandha has tikta, katu and kashaya rasa, laghu and snigdha guna, madhura vipaka and kapha vataghna properties. Tikta rasa has lekhana guna ${ }^{9}$ that scraps out excessive kapha and meda from srotas. Hypertension is a vata predominant tridoshaja vyadhi and Ashwagandha by virtue of its various properties alleviates morbid vata and kapha doshas. Ashwagandha also has a anti anxiety effect, ${ }^{10}$ which calms the fuelled anxiety that accompanies stressful life style. Due to sedative effect, it controls sympathetic over activity and thus reduces the elevated blood pressure. Thus, Ashwagandha can help in managing hypertension the psychosomatic disease where Manovaha srotas is also actively involved in the pathogenesis. Gokshura has been described in Mutra virechniya gana. Gokshura helps in alleviation of vata and pitta dosha due to it sheeta virya, madhura rasa and madhura vipaka ${ }^{11}$. Its sheeta virya, increases the body kleda (watery content) and hence increases the amount of urine formation. Its main action is to inhibit the re-absorption of water from renal tubules leading to diuresis and thus acts as anti hypertensive drug ${ }^{12}$. Parseek yavani has tikta and katu rasa, ruksha guna ushna veerya and katu vipaka. ${ }^{13}$ Hypertension as earlier said is a tridoshaja vyadhi with vata predominance. This drug alleviates vitiated vata by virtue of its ushna veerya and vitiated kapha by its tikta katu rasa, ruksha guna, ushna veerya and katu vipaka. Triphala is a combination of Haritaki, Vibhitaka and amla in equal quantities and finds widespread description in various ayurvedic texts. Haritaki is predominately vatahara ${ }^{14}$, Vibhitaka is predominately pittahara ${ }^{15}$, and Amalaki is predominately kaphahara ${ }^{16}$. Thus, combination of these fruits in Triphala helps in alleviation of vitiated vata, pitta and kapha dosha. Triphala possess Medohara properties ${ }^{17}$ and it is evident from various studies that high cholesterol level and obesity ${ }^{18}$ are the contributory factors of hypertension so it helps in controlling hypertension. Shirodhara is extremely beneficial for people suffering from imbalance of vata and pitta. Shirodhara is one of the effective ways of managing hypertension. This not only controls hypertension but also purifiers and detoxifies the body and is used to manage physical and mental exertion and fatigue. 
So, Shirodhara was done with Triphala Siddha jala in addition to the oral administration of Jatamansyadi Kwatha.

\section{CONCLUSION}

On clinical evaluation, the trial drug Jatamansyadi Kwatha has proved effective and safe remedy for patients of hypertension. Therapy given in Group-II i.e., Jatamansyadi Kwatha along with Shirodhara has shown the marginal advantage over the therapy given in Group-I i.e., Jatamansyadi Kwatha alone, in reducing elevated blood pressure. Much better reduction in subjective parameters was observed in Group-II parameters in comparison to Group-I parameters. However statistically highly significant reduction in both systolic and diastolic blood pressure was observed in both the groups but the intergroup difference between the therapies was statistically insignificant. No untoward effect of therapy was observed in both the groups during the entire trial period. Ayurvedic formulation Jatamansyadi Kwatha showed very good results in hypertensive patients on both the subjective as well as objective parameters.

Table 1: Ingredients of Jatamansyadi Kwath

\begin{tabular}{|c|c|c|c|c|c|}
\hline S. No. & Name of Ingredients & Botanical name & Family & Part used & Proportion \\
\hline 1. & Jatamansi & Nardostachys jatamansi & Valerianaceae & Root & 8 parts \\
\hline 2. & Gokshura & Tribulus terrestris & Zygophyllaceae & Fruit & 8 parts \\
\hline 3. & Ashwagandha & Withania somnifera & Solanaceae & Root & 2 parts \\
\hline 4. & Parseek Yavani & Hyoscyamus niger & Solanaceae & Seeds & 1 part \\
\hline
\end{tabular}

Table 2: Ingredients of Shirodhara (Triphala Siddha Jal)

\begin{tabular}{|r|c|c|c|c|c|}
\hline S. No. & Name of ingredients & Botanical name & Family & Part used & Proportion \\
\hline 1. & Haritaki & Terminalia chebula & Combretaceae & Pericarp & 1 Part \\
\hline 2. & Vibhitaki & Terminalia bellerica & Combretaceae & Pericarp & 1 Part \\
\hline 3. & Amalaki & Emblica officinalis & Euphorbiaceae & Pericarp & 1 Part \\
\hline
\end{tabular}

Table 3: Objective Criteria of Assessment

\begin{tabular}{|c|c|}
\hline S. No. & Objective criteria \\
\hline 1. & Blood Pressure \\
\hline 2. & Pulse Pressure \\
\hline 3. & Mean Arterial pressure \\
\hline 4. & Pulse Rate \\
\hline
\end{tabular}

Table 4: Subjective criteria of assessment were graded from 0 to 3 according to severity

\begin{tabular}{|c|c|c|}
\hline S. No. & Name of Subjective Criteria & Score \\
\hline 1. & \multicolumn{2}{|l|}{ Shiraruja (Headache) } \\
\hline & No Headache & 0 \\
\hline & Mild headache and able to do routine work & 1 \\
\hline & Moderate headache which hampers routine work & 2 \\
\hline & Severe Headache unable to any work & 3 \\
\hline \multirow[t]{5}{*}{2.} & \multicolumn{2}{|l|}{ Bhrama (Giddiness) } \\
\hline & No giddiness & 0 \\
\hline & Mild Giddiness patient is able to do routine work & 1 \\
\hline & Moderate giddiness which hampers routine work & 2 \\
\hline & Severe continuous giddiness, patient is unable to do any work & 3 \\
\hline \multirow[t]{5}{*}{3.} & \multicolumn{2}{|l|}{ Hriddrava (Palpitation) } \\
\hline & No palpitation & 0 \\
\hline & Occasional palpitation & 1 \\
\hline & Palpitation which hampers routine work & 2 \\
\hline & Continuous palpitation & 3 \\
\hline \multirow[t]{5}{*}{4.} & \multicolumn{2}{|l|}{ Shwasa Kricchrita (Breathlessness) } \\
\hline & No dyspnoea on exertion & 0 \\
\hline & Mild dyspnoea on exertion and able to do routine work & 1 \\
\hline & Moderate dyspnoea on little exertion and unable to do routine work & 2 \\
\hline & Severe dyspnoea with exertion and unable to do routine work & 3 \\
\hline
\end{tabular}

Table 5: Age wise distribution of 20 patients of Hypertension

\begin{tabular}{|c|c|c|c|c|}
\hline \multirow{2}{*}{$\begin{array}{c}\text { Age Group } \\
\text { (Years) }\end{array}$} & \multicolumn{2}{|c|}{ Group-I } & \multicolumn{2}{c|}{ Group-II } \\
\cline { 2 - 5 } & No. of Patients & Percentage & No. of Patients & Percentage \\
\hline $21-40$ & 7 & 70 & 7 & 70 \\
\hline $41-60$ & 1 & 10 & 2 & 20 \\
\hline $61-80$ & 2 & 20 & 1 & 10 \\
\hline
\end{tabular}


Vijay Chaudhary et al / Int. J. Res. Ayurveda Pharm. 12 (2), 2021

Table 6: Occupation wise distribution of 20 patients of Hypertension

\begin{tabular}{|c|c|c|c|c|}
\hline \multirow{2}{*}{ Occupation } & \multicolumn{2}{|c|}{ Group-I } & \multicolumn{2}{c|}{ Group-II } \\
\cline { 2 - 5 } & No. of Patients & Percentage & No. of Patients & Percentage \\
\hline Private Jobs & 1 & 10 & 6 & 60 \\
\hline Housework & 5 & 50 & 4 & 40 \\
\hline Retired & 4 & 40 & 0 & 0 \\
\hline
\end{tabular}

Table 7: Life Style Wise Distribution of 20 patients of Hypertension

\begin{tabular}{|c|c|c|c|c|}
\hline \multirow{2}{*}{ Life Style } & \multicolumn{2}{|c|}{ Group-I } & \multicolumn{2}{c|}{ Group-II } \\
\cline { 2 - 5 } & No. of Patients & Percentage & No. of Patients & Percentage \\
\hline Hard working & 0 & 0 & 2 & 20 \\
\hline Active life style & 9 & 90 & 6 & 60 \\
\hline Sedentary & 1 & 10 & 2 & 20 \\
\hline
\end{tabular}

Table 8: Diet Wise Distribution of 20 patients of Hypertension

\begin{tabular}{|c|c|c|c|c|}
\hline \multirow{2}{*}{ Diet } & \multicolumn{2}{|c|}{ Group-I } & \multicolumn{2}{c|}{ Group-II } \\
\cline { 2 - 5 } & No. of Patients & Percentage & No. of Patients & Percentage \\
\hline Vegetarian & 1 & 10 & 2 & 20 \\
\hline Mixed & 9 & 90 & 8 & 80 \\
\hline
\end{tabular}

Table 9: Addiction Wise Distribution of 20 patients of Hypertension

\begin{tabular}{|c|c|c|c|c|}
\hline \multirow{2}{*}{ Addiction } & \multicolumn{2}{|c|}{ Group-I } & \multicolumn{2}{c|}{ Group-II } \\
\cline { 2 - 5 } & No. of Patients & Percentage & No. of Patients & Percentage \\
\hline Smoking & 1 & 10 & 2 & 20 \\
\hline Alcohol & 1 & 10 & 1 & 10 \\
\hline Smoking and Alcohol & 3 & 30 & 4 & 40 \\
\hline Tea/Coffee & 4 & 40 & 2 & 20 \\
\hline No Addiction & 1 & 10 & 1 & 10 \\
\hline
\end{tabular}

Table 10: Signs and Symptoms Wise Distribution of 20 patients of Hypertension

\begin{tabular}{|c|c|c|c|c|}
\hline \multirow{2}{*}{ Signs and Symptoms } & \multicolumn{2}{|c|}{ Group-I } & \multicolumn{2}{c|}{ Group-II } \\
\cline { 2 - 5 } & No. of Patients & Percentage & No. of Patients & Percentage \\
\hline Shiraruja (Headache) & 6 & $60 \%$ & 4 & $40 \%$ \\
\hline Hriddravata (Palpitation) & 2 & $20 \%$ & 2 & $20 \%$ \\
\hline Bhrama (Giddiness) & 4 & $40 \%$ & 2 & $20 \%$ \\
\hline Shwasa kricchrita (Breathlessness) & 2 & $20 \%$ & 1 & $10 \%$ \\
\hline
\end{tabular}

Table 11: Effect of therapy on Blood Pressure on 20 patients of Hypertension

\begin{tabular}{|c|c|c|c|c|c|c|c|c|}
\hline \multirow{2}{*}{ Group } & \multirow{2}{*}{$\begin{array}{c}\text { Blood } \\
\text { pressure }\end{array}$} & \multicolumn{2}{|c|}{$\begin{array}{c}\text { Mean Score } \\
\text { (in mm of Hg) }\end{array}$} & \multirow{2}{*}{$\begin{array}{c}\text { \% } \\
\text { Change }\end{array}$} & SD & SE \pm & T & P \\
\cline { 3 - 9 } & & $\mathbf{B T}$ & $\mathbf{A T}$ & & & & & \\
\hline \multirow{2}{*}{ Group-I } & Systolic & 143.20 & 137.00 & 3.916 & 2.271 & 0.718 & 7.799 & $<0.001$ \\
\cline { 2 - 10 } & Diastolic & 96.80 & 79.20 & 8.755 & 3.373 & 1.067 & 7.125 & $<0.001$ \\
\hline \multirow{2}{*}{ Group-II } & Systolic & 146.20 & 123.60 & 11.85 & 4.81 & 1.522 & 10.90 & $<0.001$ \\
\cline { 2 - 10 } & Diastolic & 94.20 & 78.60 & 10.685 & 6.186 & 1.956 & 4.805 & $<0.001$ \\
\hline
\end{tabular}

BT: Before Treatment, AT: After Treatment

Table 12: Effects of therapy on Mean Arterial Pressure on 20 patients of Hypertension

\begin{tabular}{|c|c|c|c|c|c|c|c|}
\hline Group & \multicolumn{2}{|c|}{$\begin{array}{c}\text { Mean Score } \\
\text { (mm of Hg) }\end{array}$} & \multirow{2}{*}{$\begin{array}{c}\text { \% } \\
\text { Change }\end{array}$} & SD & SE \pm & T & P \\
\cline { 2 - 6 } & BT & AT & & & & & \\
\hline Group-I & 103.70 & 97.56 & 5.802 & 8.9 & 2.8 & 2.11 & 0.063 \\
\hline Group-II & 107.77 & 97.31 & 5.304 & 2.659 & 0.841 & 6.492 & $<0.001$ \\
\hline
\end{tabular}

BT: Before Treatment, AT: After Treatment

Table 13: Effects of therapy on pulse Pressure on 20 patients of Hypertension

\begin{tabular}{|c|c|c|c|c|c|c|c|}
\hline \multirow{2}{*}{ Group } & \multicolumn{2}{|c|}{$\begin{array}{c}\text { Mean Score } \\
\text { (mm of Hg) }\end{array}$} & \multirow{2}{*}{$\begin{array}{c}\text { \% } \\
\text { Change }\end{array}$} & SD & SE \pm & T & P \\
\cline { 2 - 5 } & BT & AT & & & & & \\
\hline Group-I & 56.400 & 60.0 & 6.38 & 11.8 & 3.733 & 0.964 & 0.360 \\
\hline Group-II & 52.45 & 45 & 13.4 & 7.84 & 2.48 & 2.821 & 0.020 \\
\hline
\end{tabular}

BT: Before Treatment, AT: After Treatment 
Vijay Chaudhary et al / Int. J. Res. Ayurveda Pharm. 12 (2), 2021

Table 14: Effects of therapy on Pulse Rate on 20 patients of Hypertension

\begin{tabular}{|c|c|c|c|c|c|c|c|}
\hline Group & \multicolumn{2}{|c|}{$\begin{array}{c}\text { Mean Score } \\
\text { (per/minute) }\end{array}$} & \multirow{2}{*}{$\begin{array}{c}\text { \% } \\
\text { Change }\end{array}$} & SD & SE \pm & T & P \\
\cline { 2 - 5 } & BT & AT & & & & & \\
\hline Group-I & 81.80 & 77.200 & 5.623 & 7.245 & 2.291 & 2.008 & 0.076 \\
\hline Group-II & 87.8 & 82.4 & 5.287 & 11.31 & 3.57 & 1.286 & 0.231 \\
\hline
\end{tabular}

BT: Before Treatment, AT: After Treatment

Table 15: Comparison of effects of therapies on various parameters

\begin{tabular}{|c|c|c|c|}
\hline Group-I V/s Group-II Comparison & Mean difference & T & p \\
\hline Systolic Blood Pressure & 9.6 & 5.367 & $<0.001$ \\
\hline Diastolic Blood Pressure & 1.8 & 0.808 & $<0.439$ \\
\hline Mean Arterial Pressure & 1.139 & 0.379 & 0.709 \\
\hline Pulse Pressure & 2.200 & 0.914 & 0.373 \\
\hline Pulse Rate & 2.00 & 0.642 & 0.529 \\
\hline Shiraruja (Headache) & 0.90 & 2.862 & 0.010 \\
\hline Bhrama (Giddiness) & 1.0 & 3.39 & 0.003 \\
\hline Hriddravata (Palpitation) & 0.800 & 2.53 & 0.021 \\
\hline Shwas (Breathlessness) & 1.4 & 4.3 & $<0.001$ \\
\hline
\end{tabular}

Table 16: Effect of therapy on Lipid Profile in Group-I

\begin{tabular}{|c|c|c|c|c|c|c|c|}
\hline \multirow[t]{2}{*}{ Lipid Profile } & \multicolumn{2}{|c|}{ Mean Score (mg/dl) } & \multirow{2}{*}{$\begin{array}{c}\% \\
\text { Change }\end{array}$} & \multirow[t]{2}{*}{ SD } & \multirow[t]{2}{*}{ SE+ } & \multirow[t]{2}{*}{ ' $t$ ' } & \multirow[t]{2}{*}{$\mathbf{P}$} \\
\hline & BT & $\mathbf{A T}$ & & & & & \\
\hline S. Cholesterol & 160.40 & 149.2 & 20.85 & 59.89 & 18.94 & 2.070 & 0.068 \\
\hline S. Triglyceride & 140.50 & 100.55 & 39.9 & 61.36 & 20.45 & 3.15 & 0.014 \\
\hline HDL & 44.2 & 51.8 & 14.67 & 15.24 & 4.81 & 1.577 & 0.149 \\
\hline LDL & 109.2 & 68.2 & 37.61 & 31.85 & 10.07 & 4.071 & 0.003 \\
\hline VLDL & 25.100 & 24.10 & 15.13 & 16.026 & 05.068 & 0.75 & 0.473 \\
\hline
\end{tabular}

BT: Before Treatment, AT: After Treatment

Table 17: Effect of therapy on Lipid Profile in Group-II

\begin{tabular}{|c|c|c|c|c|c|c|c|}
\hline \multirow{2}{*}{ Lipid Profile } & \multicolumn{2}{|c|}{$\begin{array}{c}\text { Mean Score } \\
(\mathbf{m g} / \mathbf{d l})\end{array}$} & $\begin{array}{c}\text { \% } \\
\text { Change }\end{array}$ & \multirow{2}{*}{ SD } & SE+ & 't' & \multirow{2}{*}{ P } \\
\cline { 2 - 8 } & $\mathbf{B T}$ & $\mathbf{A T}$ & & & & & \\
\hline S. Cholesterol & 202.5 & 190.8 & 25.277 & 30.865 & 9.760 & 5.246 & $<0.001$ \\
\hline S. Triglyceride & 155.5 & 87.22 & 43.95 & 63.68 & 21.23 & 3.219 & 0.012 \\
\hline HDL & 47.2 & 49.8 & 7.2 & 4.993 & 1.579 & 2.153 & 0.060 \\
\hline LDL & 125.6 & 83.3 & 33.84 & 23.53 & 7.44 & 5.683 & $<0.001$ \\
\hline VLDL & 31.7 & 18.9 & 40.37 & 12.13 & 3.83 & 3.335 & 0.009 \\
\hline
\end{tabular}

\section{ACKNOWLEDGEMENT}

The authors are thankful to all the patients who willingly participated in this study. We are also thankful to the management of Rajiv Gandhi Govt. Post Graduate Ayurvedic College Hospital Paprola H.P. for providing necessary assistance for completion of this research project.

\section{REFERENCES}

1. Chobanian AV, Bakris GL, Black HR, et. al. Seventh Report of the Joint National Committee on Prevention, Detection, Evaluation and Treatment of High Blood Pressure. Hypertension 2003 December; 42(6): 1206-52.

2. Vasan RS, Beiser A, Seshadris, et. al. Residual life time risk for developing hypertension in middle aged women and men: The Framingham Heart Study. JAMA 2002; 287: 1003-10.

3. Shastri Dutta Ambika. Sushruta Samhita of Maharshi Sushruta, edited with Ayurveda tattva Sandipika, Sutra Sthana 15, Chaukhambha Sanskrit Sansthan. Varanasi. $14^{\text {th }}$ edition; 2003.

4. Shastri Dutta Ambika. Sushruta Samhita of Maharshi Sushruta, edited with Ayurveda tattva Sandipika, Nidana Sthana 1/17-18, Chaukhambha Sanskrit Sansthan. Varanasi. $14^{\text {th }}$ edition; 2003.
5. Siddhayog Sangraha Vaidya Yadavji Trikamji Acharya published by Baijnath Ayurved Bhavan Nagpur Vataroga 20/10. p. 102.

6. Agnivesha, Charaka Samhita with Ayurveda Deepika Commentary of Chakrapani Datta, Sutra Sthana, Chapter 21, verse 36, published by Chaukhambha Sanskrit Sansthan; Varanasi; 2004.

7. The Ayurvedic Pharmacopoeia of India, Part I, Volume I; 1989. p. 63.

8. V. Velpandian, N. Anbu, S. Elangovan, M. Mohamed Musthafa. Antihypertensive Activity of Nardostachys jatamansi In Hypertensive Rats Following Renal Gold Blatt Occlusion Method. World Journal of Pharmaceutical Research ISSN 2277 - 7105 Volume 3, Issue 8. p. 769-777.

9. The Ayurvedic Pharmacopoeia of India, Part I, Volume I; 1989. p. 19.

10. Pratte MA, Nanavati KB, Young V, Morley CP. An alternative treatment for anxiety: a systematic review of human trial results reported for the Ayurvedic herb Ashwagandha (Withania somnifera). J Altern Complement Med 2014; 20(12): 901-8. DOI: 10.1089/acm.2014.0177

11. The Ayurvedic Pharmacopoeia of India, Part I, Volume I; 1989. p. 49.

12. Singh RG, et al., Experimental Evaluation of Diuretic Action of Herbal Drug Tribulus terrestris on albino rats, Jour. of Res \& Edu. In Indian Medicine 1991; 10(1): 19-21. 
13. Bhava Prakash Nighantu (Indian Materia Medica) of Shri Bhava Mishra 18 /80, Hindi commentary by Chunekar K.K., Chaukhambha Varanasi; 2002. p. 30.

14. The Ayurvedic Pharmacopoeia of India, Part I, Volume I; 1989. p. 14

15. The Ayurvedic Pharmacopoeia of India, Part I, Volume I; 1989. p. 7.

16. The Ayurvedic Pharmacopoeia of India, Part I, Volume I; 1989. p. 34

17. Tripathi Dutt Ravi. Ashtanga Sangraha of Shrimad Vriddha Vagbhata, Sutra Sthana 12/47 Chaukhambha Sanskrit Pratishthana Delhi; 2006.
18. Patil Shashikala A, Savanur Prasanna V., Shiramagond Basavaraj, Shailaja. J. R. A Clinical Study on Efficacy of Triphala Churna with Madhu in Sthoulya. PIJAR 2017; 1(4): 29-35.

\section{Cite this article as:}

Vijay Chaudhary et al. A Clinical Study to evaluate the effect of Jatamansyadi Kwatha and Shirodhara in the management of Hypertension. Int. J. Res. Ayurveda Pharm. 2021;12(2):4-10 http://dx.doi.org/10.7897/2277-4343.120236

\section{Source of support: Nil, Conflict of interest: None Declared}

Disclaimer: IJRAP is solely owned by Moksha Publishing House - A non-profit publishing house, dedicated to publishing quality research, while every effort has been taken to verify the accuracy of the content published in our Journal. IJRAP cannot accept any responsibility or liability for the site content and articles published. The views expressed in articles by our contributing authors are not necessarily those of IJRAP editor or editorial board members. 